\title{
ANALISIS KEMAMPUAN PEMAHAMAN MATEMATIK PADA MATERI BANGUN DATAR DENGAN PENDEKATAN KONTEKSTUAL
}

\author{
Akhmad Khotib ${ }^{1}$ \\ ${ }^{1}$ IKIP Siliwangi, Jl. Terusan Jenderal Sudirman, Cimahi, Jawa Barat, Indonesia \\ 11akhmadkhotib13@gmail.com
}

Diterima: 3 Maret 2019; Disetujui: 31 Mei 2019

\begin{abstract}
The purpose of this study is to see the level of mathematical comprehension ability in a junior high school with a contextual approach. the subject of a study was students from class VII, with the number of students 21 people in the quantitative descriptive method. Research instruments are 5 essay questions with indicators of mathematical comprehension ability in Flat Wake material accompanied by interviews with students. The results of the study prove the ability of mathematical understanding in mathematics lessons using a contextual approach to the good category.
\end{abstract}

Keywords: Contextual approval, mathematical understanding support

\begin{abstract}
Abstrak
Maksud penelitian ini yaitu ingin melihat tingkat kemampuan pemahaman matematik disuatu SMP dengan pendekatan kontekstual. subyek dari suatu penelitian ini siswa dari kelas VII, dengan jumlah siswa 21 orang pada metode deskriptif kuantitatif. Istrumen penelitian adalah 5 soal essay dengan indikator kemampuan pemahaman matematik pada materi Bangun Datar disertai dengan wawancara kepada siswa. Hasil penelitian membuktikan kemampuan pemahaman matematik pada pelajaran matematika dengan katagori baik.
\end{abstract}

Kata Kunci: Pendekatan kontekstual, Kemampuan pemahaman matematik

How to cite: Khotib, A. (2019). Analisis Analisis Kemampuan Pemahaman Matematik pada Materi Bangun Datar dengan Pendekatan Kontekstual. JPMI- Jurnal Pembelajaran Matematika Inovatif, 2 (3), 119-126.

\section{PENDAHULUAN}

Sejalan dengan berkembangnya teknelogi dan ilmu pengetahuan, maka siswa dituntut untuk terus mengembangangkan kemampuannya dalam berbagai pembelajaran, dimana pembelajaran tersebut akan didapatkan di sekolah. Salah satu pembelajaran yang diharuskan dikembangkan pada kemampuan pemahaman yaitu pelajaran matematika. Karena matematika merupakan unsur dari ilmu pengetahuan. Matematika akan selalu terikat pada kehidupan sesungguhnya . Syamsudin, Afrilianto, \& Rohaeti (2018), menjelaskan bahwa matematika adalah suatu ilmu yang harus dipelajari pada setiap jenjang pendidikan baik itu SD ataupun pendidikan lanjutan.

Kemampuan pemahaman merupakan tujuan yang penting dari sebuah pembelajaran, maka dari itu materi - materi yang diberikan kepada siswa bukan dihafal saja, dengan pemahaman maka siswa lebih mengerti konsep atau ide pada pelajaran metematika. Purwanto ( Harja: 2012 ), menjelaskan pemahaman adalah kepiawaian siswa untuk menguasai arti atau suatu konsep 
serta keadaan secara nyata yang dapat diketahuinya. Menurut Sariningsih (2014), belajar matematika memerlukan suatu konsep matematik untuk menyelesaikan dalam suatu kasus dalam belajar serta ilmu pengetahuan lainnya.

Pada pelajaran matematika siswa sangat sukar dalam menuntaskan soal matematika. Padahal matematika merupakan untuk dimengerti oleh semua siswa, karena hampir semua pembelajaran terdapat matematika salah satu contoh pada pembelajaran IPA serta Olah Raga. Maka dari pentingnya pemahaman matematik dalam suatu pembelajaran matematika. Aripin (2016), menganggap bahwa setiap umat penting untuk menguasai matematika.

Pada saat mempelajari matematika siswa akan mengalami kendala dalam belajar, penyebab siswa mengalami kendala mempelajari matematika yaitu minimnya siswa menguasai tentang konsep matematika, Menyebabkan rendahnya kemampuan pemahaman pada saat mempelajari matematik. Menurut Jamal, (2019) bahwa, problem siswa dalam menguasai matematika adalah kesulitan konsep. Wahyudin (Anggraeni, 2012: 1) mengemukakan penyebab siswa tidak mengerti dalam mendalami matematika adalah kurang memiliki pemahaman mengenal suatu konsep dasar matematika. Maka dari itu menguasai konsep matematika menentukan keberhasilan siswa mempelajari matematika. Menurut Afrilianto (2012), berpendapat bahwa pemahaman konsep menentukan keberhasilan dari suatu pembelajar matematika.

Selain pemahaman konsep faktor lain penyebab rendanya pemahaman pada pelajaran matematika yaitu motivasi siswa, motivasi merupakan hal yang sangat terpenting untuk mengembangkan kemampuan siswa dalam menguasai suatu pembelajaran matematika, dengan adanya motivasi dalam diri seorang siswa, maka akan lebih tekun untuk memperjari matematika, karena memiliki keingginan untuk meraih suatu tujuan yaitu menguasai suatu pembelajaran matematika sehingga akan muncul motivasi pada siswa. Menurut Kurniawan \& Wustqa (2014), berpendapat bahwa motivasi merupakan proses untuk menghasut/mendorong dan mendukung dalam menggapai suatu tujuan tertentu.

Dalam meninggikan kemampuan pemahaman siswa, tentang pelajaran matematika maka perlu memilih suatu pendekatan dan metode yang inovatif. Pendekatan yang dapat menambah kemampuan pemahaman yaitu pendekatan kontekstual. Menurut Sariningsih (2014), mengemukakan pendekatan kontekstual merupakan pembelajaran yang dapat menciptakan keadaan kelas yang kondusif, maka akan menambah kemampuan pemahaman matematik. Kesimpulannya adalah kemampuan matematik merupakan kemampuan tidak hanya mengingat saja, tetapi harus menguasai konsep atau ide pelajaran tersebut. Dengan kemampuan pemahaman ini siswa bisa menyelesaikan suatu permasalahan pembelajaran tersebut.

Dari penyataan diatas maka indikator yang penulis pakai untuk penilitian adalah Kemampuan menyatakan kembali konsep yang dipelajari, Kemampuan untuk mengklasifikasikan objekobjek berdasarkan sifat-sifat tertentu, kemampuan menyebutkan suatu model dan bukan merupakan model dari konsep, Kemampuan menggunakan serta memilih dan dapat memamfaatkan suatu operasi tertentu, Kemampuan mengaplikasikan konsep pemecahan masalah. Adapun maksud penelitian ini adalah ingin mengetahui taraf kemampuan pemahaman matematik siswa SMP.

\section{METODE}

Peneilitian ini merupakan deskriptif kualitatif. Penelitian ini melibatkan siswa SMP kelas VII berjumlah 21 orang. Dalam mengumpulkan hasil penelitian menggunakan tes dan wawancara, 
agar hasil yang diperoleh lebih jelas dan akurat. Soal yang di teskan sebanyak 5 soal essay dengan indikator kemampuan pemahaman.

Tes ini berdasarkan pemahaman siswa terhadap pelajaran matematika. Untuk menentukan presentase penilaian menurut Purwanto (2009:102) adalah:

$$
\mathrm{NT}=\frac{S}{\mathrm{SL}} \times 100 \%
$$

Keterangan :

NT = Nilai Presentase

$\mathrm{S} \quad=$ Skor yang diperoleh

SL $\quad=$ Skor maksimal

Adapun skor kemampuan perserta didik menurut Purwanto (2009:102) dapat dilihat berikut ini.

Tabel 1 Skor Kemampuan Pemahaman

\begin{tabular}{ll}
\hline Skor $(\%)$ & Kategori \\
\hline $86-100$ & Sangat Baik \\
$76-85$ & Baik \\
$60-75$ & Cukup \\
$55-59$ & Kurang \\
Kurang dari 55 & Kurang Sekali \\
\hline
\end{tabular}

Setelah dilakukan tes dan tanyajawab kepada siswa makan akan dilakukan suatu analisis data melalui tahapan sebagai berikut :

1. Reduksi data

2. Penyajian Data

3. Pengecekan keabsahan Data

4. Penarikan Kesimpulan

\section{HASIL DAN PEMBAHASAN}

\section{Hasil}

Dari hasil tes tersebut terdapat beberapa siswa dengan persentase $<55 \%$ dikatagorikan kurang sekali terdapat 1 siswa. Siswa dengan Persentase 55 sampai $59 \%$ dikatagorikan kurang adalah 3 siswa. Kemudian siswa dengan persentase 60 sampai 75\% dengan katagori cukup adalah 5 siswa. Sedangkan siswa dengan persentase 76 sampai 85\% dengan katagori baik adalah 10 siswa. Serta siswa dengan presentase 86 sampai $100 \%$ dengan katagori baik sekali terdapat 2 siswa.

Kemudian terdapat hasil wawancara terhadap siswa SMP di kabupaten Karawang dengan data sebagai berikut

1. Kelompok bawah 
Tabel 2. Tabel Wawancara Kelompok Rendah

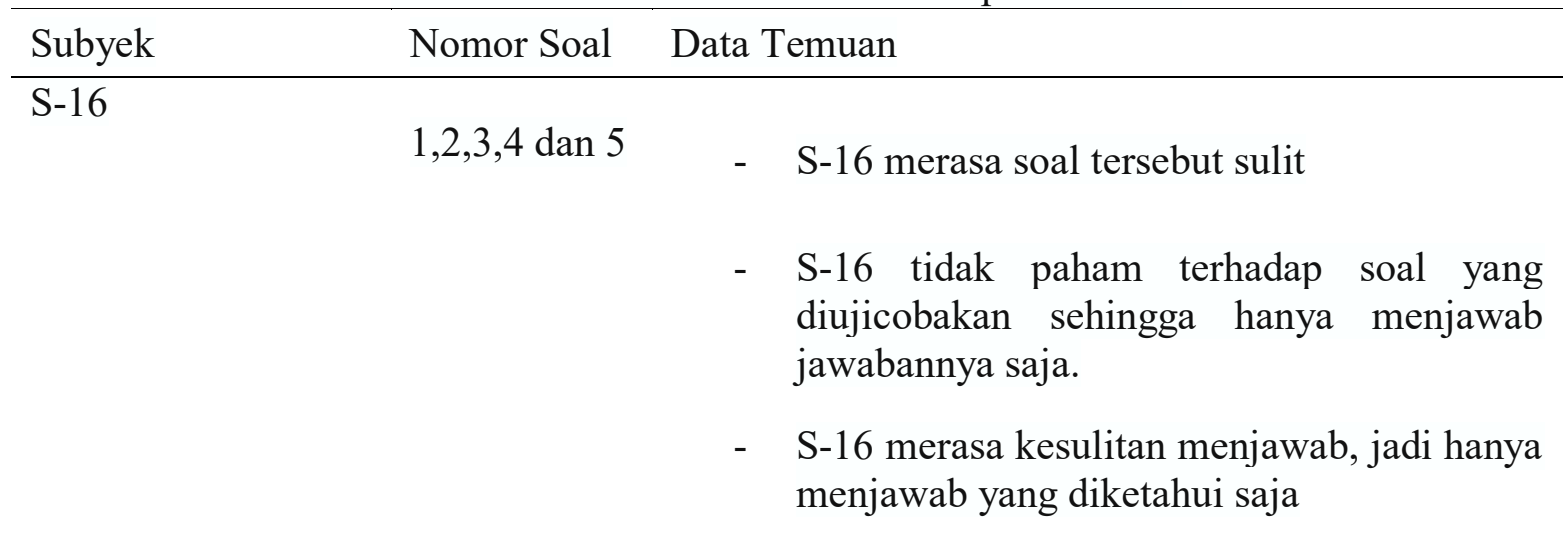

2. Kelompok Sedang

Tabel 3. Tabel Wawancara Kelompok Sendang

\begin{tabular}{|c|c|c|}
\hline Subyek & Nomor Soal & Data Temuan \\
\hline \multirow[t]{4}{*}{ S-1 } & $1,2,3,4$ dan 5 & $\begin{array}{l}\text { - Untuk menguasai soal S-1 membaca } \\
\text { beberapa kali soal tes tersebut. }\end{array}$ \\
\hline & & - $\quad$ Pada soal no 2 S-1 sudah paham. \\
\hline & & $\begin{array}{l}\text { - Soal no } 5 \text { S-1 merasa kesulitan untuk } \\
\text { mengerjakan soal tersebut. }\end{array}$ \\
\hline & & $\begin{array}{l}\text { - Soal no } 5 \text { S-1 hanya menjawab jawabannya } \\
\text { saja. }\end{array}$ \\
\hline
\end{tabular}

3. Kelompok Atas

Tabel 5. Tabel Wawancara Kelompok Atas

\begin{tabular}{|c|c|c|}
\hline Subyek & Nomor Soal & Data Temuan \\
\hline \multirow[t]{4}{*}{ S-8 } & $1,2,3,4$ dan 5 & $\begin{array}{l}\text { - Peserta didik sudah bisa menentukan } \\
\text { diketahui dari soal tersebut }\end{array}$ \\
\hline & & $\begin{array}{l}\text { - Perserta didik sudah bisa menentukan } \\
\text { bagaimana cara yang benar menjawab soal. }\end{array}$ \\
\hline & & $\begin{array}{l}\text { - Dalam kelima soal tersebut ada beberapa soal } \\
\text { yang sangat sulit yaitu no } 5\end{array}$ \\
\hline & & $\begin{array}{l}\text { - Soal no } 5 \text { sukar sehingga hanya menjawab } \\
\text { jawabannya saja }\end{array}$ \\
\hline
\end{tabular}




\section{Pembahasan}

Berdasarkan Melihat Presentase dari semua hasil uji coba, terdapat 1 Orang katagori kurang dengan Prensentase kurang dari 55\%, dapat dikatakan rata rata kemampuan pemahaman siswa baik karna hanya 1 orang yang belum menguasai soal yang diujicobakan. Itu sejalan dengan Bloom (1956) mengartikan bahwa pemahaman (comprehension) merupakan aspek yang mengacu pada kemampuan untuk mengetahui dan memahami suatu konsep dan memaknai arti suatu materi. Maksudnya adalah siswa harus mempunyai kemampuan untuk memahami inti dari pelajaran tersebut dan dapat mengerti tentang materi yang berikan oleh guru .

Pendekatan kontekstual merupakan pendekatan yang bisa menjadi pemicu untuk meningkatkan kemampuan pemahaman siswa, karena Sanjaya (2006: 109) mengemukakan bahwa pendekatan pembelajaran kontekstual adalah suatu pendekatan pembelajaran yang memusatkan kepada peran serta siswa secara maksimum, untuk dapat mencerna materi yang dipelajari, dan mengyangkutkan dengan situasi kehidupan nyata.

Menurut Jhonson (2006: 15) mengungkapkan bahwa pendekatan kontekstual adalah pembelajaran yang bertujuan membantu siswa mengetahui arti di dalam materi akademik dengan situasi kehidupan keseharian mereka, yaitu dengan situasi keadaan pribadi, sosial, dan budaya mereka. Dengan keseharian mereka yang sering jumpai setiap saat, akan membuat siswa untuk mendapati tentang inti dari materi - materi tersebut.

Salah satu materi yang diujikan oleh penguji adalah tentang bangun datar dengan soal test yang digunakan adalah kemampuan pemahaman matematik, sedangkan pada kelas yang diujicobakan menggunakan pendekatan kontekstual. Setelah diujicobakan hasilnya adalah dari 21 siswa yang belum menguasai soal tersebut terdapat 1 orang. Itu membuktikan bahwa kemampuan pemahaman siswa dapat meningkat dengan menggunakan pendekatan kontekstual.

Soal No 1.

Sebuah televisi mempunyai panjang $=x$ dan lebar $12 \mathrm{~cm}$, luas televisi itu $240 \mathrm{~cm}^{2}$.

a. Apa yang kalian ketahui dari soal tersebut?

b. Berbentuk bangun apa televisi tersebut? Jelaskan

c. Bagaimana cara kalian untuk mengetahui nilai $\mathrm{x}$ ?

d. Berapa panjang televisi tersebut ?

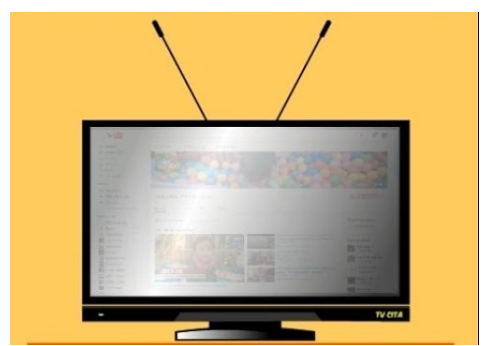

a. Kelompok Bawah

Berdasarkan hasil kutipan wawancara dan soal tes yang diujicobakan, S-16 mendapatkan skor terendah, itu karena S-16 belum begitu paham terhadap soal yang dibagikan oleh penguji.

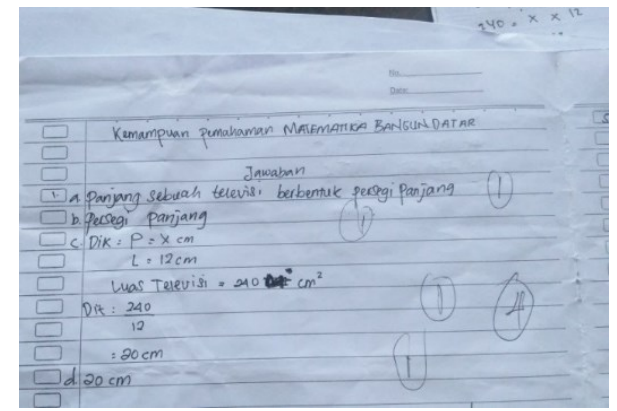

Gambar 1. Jawaban no 1. ( S16 ) 
Dari gambar 1 tersebut menunjukan S-16 belum terlalu paham sehingga tidak mampu menjawab secara benar, namun S-16 sudah berusaha menjawab namun hasilnya salah.

b. Kelompok Sedang

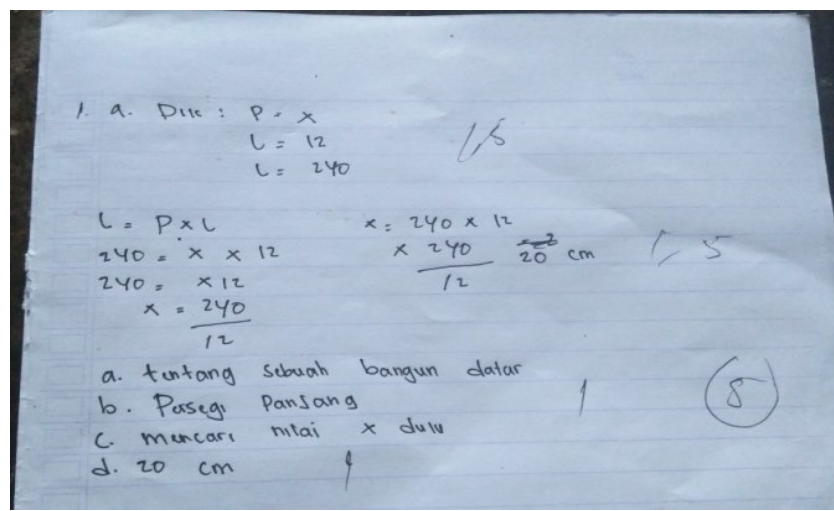

Gambar 2. Jawaban no. 1. (S-1)

Dari sebuah hasil jawaban soal no 1 oleh siswa, terlihat bahwa ( S-1 ) sudah cukup mampu dalam menyempurnakan soal tersebut dan juga sudah bisa menguasai suatu soal, dari jawaban tersebut terdapat diketahui dan ditanyakan, namun ada beberapa yang kurang lengkap jawabnnya. S-1 juga sudah mampu menyatakan kembali materi yang sudah diajarkan.

c. Kelompok Atas

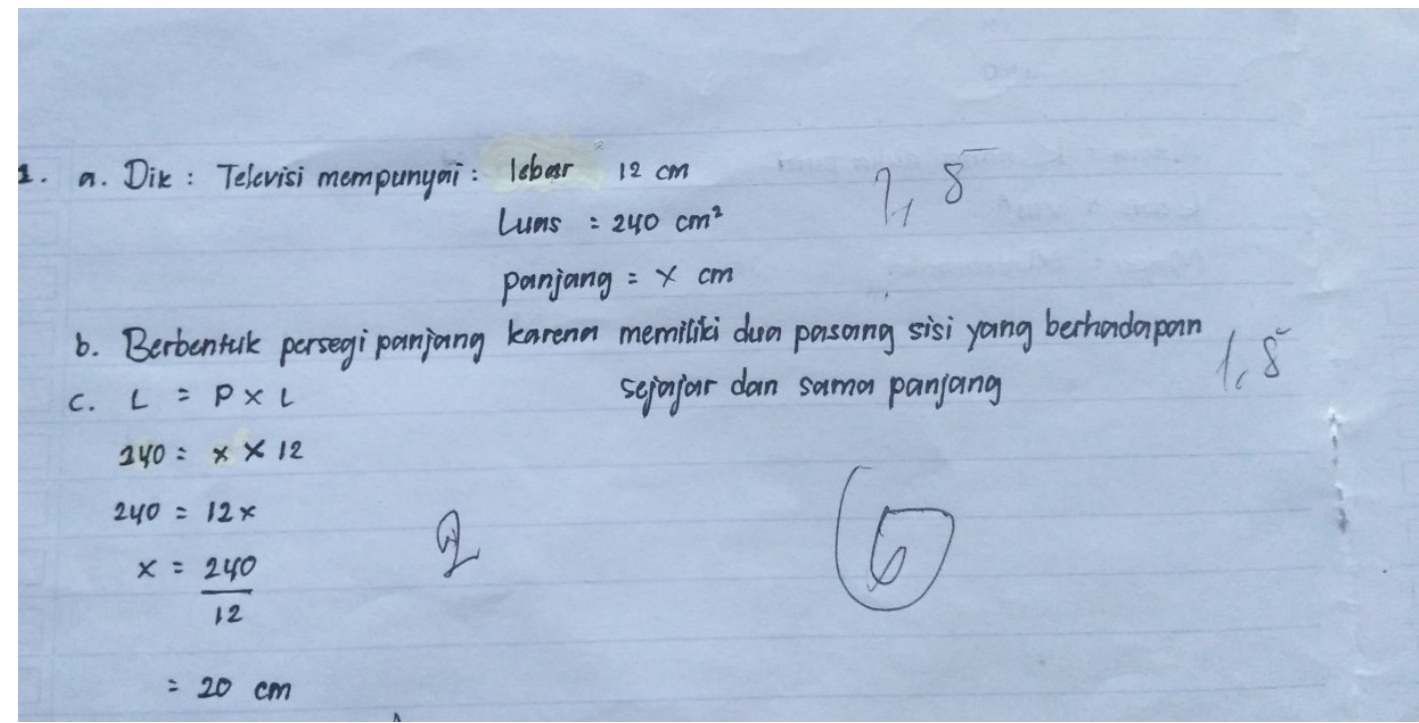

Gambar 3. Jawaban no 1. ( S-8 )

S-8 sudah mampu menguasai soal, dari tutur katanya pun sudah jelas, dan hasil jawaban nya benar. Ini menunjukan bahwa S-8 menguasai soal tersebut.

\section{KESIMPULAN}

Berdasarkan hasil dari penelitian, kemampuan pemahaman matematik di SMP sangat baik, dapat dibuktikan dari test yang telah diujicobakan bahwa siswa dikatagorikan kurang sekali terdapat 1 siswa. Siswa kelompok kurang adalah 3 siswa. Kemudian siswa dengan katagori 
cukup adalah 5 siswa. Sedangkan siswa dengan kelompok baik adalah 10 siswa. Serta siswa dengan kelompok baik sekali terdapat 2 siswa. Kesimpulan dari penelitian tersebut adalah pendekatan kontekstual sangat berakibat terhadap meningkatnya kemampuan pemahaman matematik, karena pendekatan kontekstual mengaitkan antara materi yang diajarkan dengan situasi dunia nyata siswa. Sehingga siswa dapat memahami tentang pelajaran matematika, apabila siswa sudah memahami pelajaran tersebut, maka kemampuan pemahaman matematik dengan sendiri akan meningkat.

\section{DAFTAR PUSTAKA}

Afrilianto, M. (2012). Peningkatan Pemahaman Konsep dan Kompetensi Strategis Matematis Siswa SMP dengan Pendekatan Metaphorical Thinking. Infinity Journal, 1(2), 192-202.

Aripin, U. (2016). Meningkatkan kemampuan pemahaman matematik siswa SMP melalui pendekatan pembelajaran berbasis masalah. P2M STKIP Siliwangi, 2(1), 120-127.

Jamal, F. (2019). Analisis Kesulitan Belajar Siswa dalam Mata Pelajaran Matematika Pada Materi Peluang Kelas XI IPA SMA Muhammadiyah Meulaboh Johan Pahlawan. MAJU: Jurnal Ilmiah Pendidikan Matematika, 1(1).

Kurniawan, D., \& Wustqa, D. U. (2014). Pengaruh perhatian orangtua, motivasi belajar, dan lingkungan sosial terhadap prestasi belajar matematika siswa SMP. Jurnal Riset Pendidikan Matematika, 1(2), 176-187.

Sariningsih, R. (2014). Pendekatan kontekstual untuk meningkatkan kemampuan pemahaman matematis siswa SMP. Infinity Journal, 3(2), 150-163.

Syamsudin, N., Afrilianto, M., \& Rohaeti, E. E. (2018). Meningkatkan Kemampuan Komunikasi Matematik Siswa Kelas VIII SMP Negeri 2 Cariu pada Materi Sistem Persamaan Linier Dua Variabel dengan Pendekatan Realistic Mathematic Education (RME). JPMI (Jurnal Pembelajaran Matematika Inovatif), 1(3), 313-324. 
